\title{
Clinical and economic burden of community-acquired pneumonia among adults in Europe
}

\author{
T Welte, ${ }^{1}$ A Torres, ${ }^{2}$ D Nathwani ${ }^{3}$
}

\begin{abstract}
${ }^{1}$ Klinik für Pneumologie, Medizinische Hochschule Hannover, Germany ${ }^{2}$ Pneumology Dept, Clinic Institute of Thorax (ICT), Hospital Clinic of Barcelona, Institut d'Investigations Biomèdiques August Pi i Sunyer (IDIBAPS), University of Barcelona (UB), Ciber de Enfermedades Respiratorias (Ciberes), Spain

${ }^{3}$ Infection Unit, Ninewells Hospital \& Medical School, Dundee, UK
\end{abstract}

\section{Correspondence to}

T Welte, Klinik für Pneumologie, Medizinische Hochschule Hannover, Carl Neuberg Str 1, D-30625 Hannover, Germany; welte.tobias@mh-hannover.de

Received 20 October 2009 Accepted 19 April 2010 Published Online First 20 August 2010

\begin{abstract}
It is difficult to determine the impact of communityacquired pneumonia (CAP) in Europe, because precise data are scarce. Mortality attributable to CAP varies widely between European countries and with the site of patient management. This review analysed the clinical and economic burden, aetiology and resistance patterns of CAP in European adults. All primary articles reporting studies in Europe published from January 1990 to December 2007 addressing the clinical and economic burden of CAP in adults were included. A total of 2606 records were used to identify primary studies. CAP incidence varied by country, age and gender, and was higher in individuals aged $\geq 65$ years and in men.

Streptococcus pneumoniae was the most common agent isolated. Mortality varied from $<1 \%$ to $48 \%$ and was associated with advanced age, co-morbid conditions and CAP severity. Antibiotic resistance was seen in all pathogens associated with CAP. There was an increase in antibiotic-resistant strains, but resistance was not related to mortality. CAP was associated with high rates of hospitalisation and length of hospital stay. The review showed that the clinical and economic burden of CAP in Europe is high. CAP has considerable long-term effects on quality of life, and long-term prognosis is worse in patients with pneumococcal pneumonia.
\end{abstract}

Although data are available from a number of prospective studies and national databases, it is difficult to determine the clinical and economic impact of community-acquired pneumonia (CAP) in European adults for a number of reasons. For example, only Finland, Spain and the UK have precise epidemiological data on CAP. Mortality attributable to CAP varies widely between European countries and with the site of patient management. ${ }^{1}$ The burden of CAP may be underestimated because a universally recognised definition of CAP is lacking. Other reasons include difficulties in obtaining samples for culture because of the lack of a productive cough and frequent use of antibiotics before diagnosis. Technical limitations of diagnostic tests may also prevent the accurate identification of a pathogen. ${ }^{2}$ This, in turn, may result in empiric treatment of outpatients with antibiotics. Given that most patients are treated on an outpatient basis and a substantial proportion of studies are based on hospitalised patients, the true extent of CAP is not known. ${ }^{3}$

The risk of death from CAP is linked to increasing age. In a Finnish study, the incidence of CAP rose dramatically with age, with a sixfold increase in incidence between ages 30-44 years and $\geq 75$ years. $^{3}$ In Portugal, case fatality rates were $4.5 \%$ for patients aged $18-50$ years, $19.4 \%$ for those aged $\geq 50$ years and $24.8 \%$ for those aged $\geq 75$ years. ${ }^{4}$ A UK study reported case-fatality rates of $5.6 \%$ in those aged $<65$ years and $47.2 \%$ for those aged $\geq 85$ years. This study also found a 12 fold higher $O R$ for death within 30 days of hospital admission for adults aged $\geq 85$ years than for those aged $<65$ years. ${ }^{5}$ With the projected increase of those aged $\geq 65$ years to $20 \%$ of the adult population in developed regions of the world by $2025,{ }^{6}$ the burden of CAP will be felt even more acutely in the years to come.

Although many country-specific reports on CAP in Europe are available, a comprehensive assessment among adults has not been reported recently. We reviewed the published literature to define the clinical and economic burden of CAP in adults. Among the topics considered were incidence of morbidity and mortality, mortality-associated risk factors, quality of life, costs of care and duration of hospital stay. Our review also investigated current aetiology and patterns of antibiotic resistance across Europe.

\section{METHODS}

The most recent guidelines of the British Thoracic Society (2005) were used to define CAP: pneumonia should be suspected if a patient has an acute cough and one of the following signs or symptoms: new focal chest signs, dyspnoea, tachypnoea, fever lasting $>4$ days and a diagnosis confirmed by chest radiograph. ${ }^{7}$

\section{Inclusion and exclusion criteria}

All primary articles reporting studies from the European countries or regions listed below that addressed the clinical and economic burden of CAP among adults were included. Studies conducted prior to 1990 were included if they were published in 1990 or later. Studies with enrollees aged $<18$ years were excluded (figure 1 ).

The literature search was conducted in February 2008. MEDLINE and EMBASE databases were searched for literature published from January 1990 to December 2007 inclusive. The computer searches and reference lists of all of the retrieved articles were reviewed by investigators. There were no restrictions on language or publication type. The initial search terms used were 'adults' (men and women aged $\geq 18$ years) and 'community-acquired pneumonia' or 'hospital-acquired pneumonia' or 'pneumococcal pneumonia'. The 2606 records retrieved by the search formed a database and were reviewed to identify primary studies conducted in Europe using the Boolean operator 'AND' to filter by geographical regions specific to Europe. As depicted in figure 1, additional filters narrowed the 


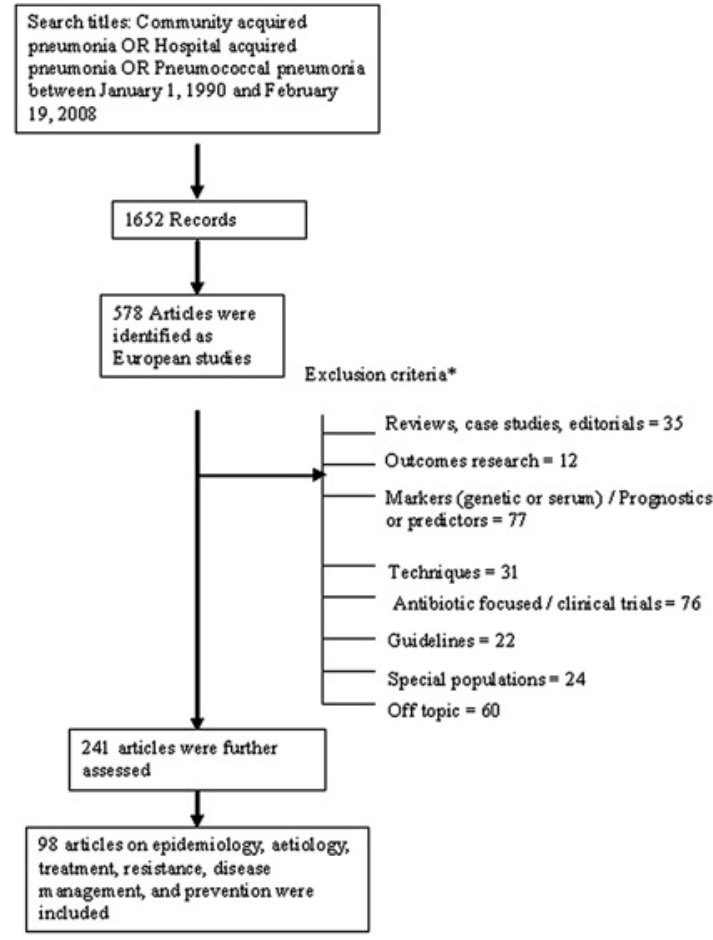

*Outcomes research included papers describing the creation or validation of questionnaires, etc; Markers included any senum or genetic marker analyses for prognostic or predic tive purposes, or clinical signs to predict outcome or prognosis; Techriques included ne $w$ techniques or papers focused on the interpretation of imaging or genetic or $\$$ rum constituents, etc; Antbiotic-focused studies or clinical trials of specific antbiotics were excluded; Guidelines included papers on the use of, change in, or improvement to tre atment guidelines; Special populations included papers foc ueed on particular patient types or disease aetiologies ie, HIV /AID or COPD patients, etc; Off topic papers were focued on specific interventions such as vaccines, the consequences of pne umonia in relation to other diseases, etc.

Figure 1 Flow diagram of the literature search strategy.

number of records to 98 . Of these, 46 primary articles dealt with aetiology, and the remaining focused on topics such as morbidity and mortality, antibiotic resistance and health-related quality-oflife issues.

The countries or regions included as keywords to identify articles specific to the European region as defined by the WHO were: Albania, Andorra, Austria, Belarus, Belgium, Bosnia, Bulgaria, Crete, Cyprus, the Czech Republic, Denmark, Estonia, Finland, France, Germany, Greece, Greenland, Hungary, Iceland, Ireland, Italy, Kazakhstan, Kosovo, Latvia, Lichtenstein, Lithuania, Luxembourg, Macedonia, Malta, Moldova, Monaco, The Netherlands, Norway, Poland, Portugal, Romania, Russia, the Russian Federation, Sardinia, Scotland, Siberia, Sicily, Slovakia, Slovenia, Spain, Sweden, Switzerland, Tajikistan,
Turkmenistan, Ukraine, the UK, Uzbekistan, the Vatican, Wales and Yugoslavia.

The references listed in the primary articles that formed the database were reviewed to validate the accuracy of the database search and to identify articles that were missed in the initial search. The database was sorted by the keywords 'epidemiology', 'aetiology', 'incidence', 'mortality', 'morbidity', 'antibiotic resistance' and 'health-related quality-of-life (HROOL)' to identify articles addressing these topics.

The literature search was updated on 15 April 2009. Fifty new studies published in 2008 and 2009 were identified using the terms 'community-acquired pneumonia' or 'hospital-acquired pneumonia' or 'pneumococcal pneumonia'. 'When sorted according to keywords, two new studies ${ }^{8} 9$ were selected.

\section{RESULTS \\ Aetiology}

Forty-six primary articles with the word 'aetiology' or 'etiology' in the title, abstract or keywords, or with a discussion of aetiology of CAP in the body of the article were identified and analysed. $^{2} 5$ 10-53 Most of these were prospective studies conducted in a hospital setting. The studies included in this analysis were not weighted to correct for differences in sample size. The 46 studies were from the following European countries: Spain (19), France (7), Italy (3), The Netherlands (3), the UK (3), Denmark (2), Germany (2), Switzerland (2), Estonia (1), Finland (1), Ireland (1), Slovenia (1) and Turkey (1). The studies used a variety of techniques to detect aetiological agents, including microbial cultures (blood, sputum, pleural fluid, bronchoalveolar lavage, aspirates from transthoracic needle aspiration and homogenised lung biopsy samples), immunoassays (urine, sputum, serum and pleural fluid) and nucleic acid amplification techniques. Data are presented as percentage means from the included studies, as was done previously. ${ }^{54}$ These studies confirmed that numerous microbial pathogens cause CAP, and the most frequently isolated pathogen in most European countries is Streptococcus pneumoniae (table 1, table 2, ${ }^{55}$ figure 2).

\section{Antibiotic resistance}

Antibiotic resistance has important clinical and economic implications. The failure of empiric antibiotic treatment due to resistance can increase the cost of treatment if a more expensive class of antibiotics or longer hospitalisation time is required. The proliferation of resistant strains of $S$ pneumoniae and other pathogens in the past 15 years threatens the successful

Table 1 Frequency of isolation of causative organisms of community-acquired pneumonia in Europe by country*2510-5355

\begin{tabular}{|c|c|c|c|c|c|c|c|c|c|c|c|c|c|}
\hline \multirow[b]{2}{*}{ Pathogen } & \multicolumn{13}{|c|}{ Percentage means of frequency of isolation in each country } \\
\hline & Denmark & Estonia & Finland & France & Ireland & Italy & Slovenia & Spain & Switzerland & Netherlands & Turkey & UK & Germany \\
\hline Streptococcus pneumoniae & 26.1 & 25.8 & 68.3 & 37.2 & 37 & 11.9 & 17.7 & 33.7 & 48.9 & 44.5 & 25.5 & 42.1 & 40 \\
\hline Legionella spp. & 4.3 & 0 & 0 & 2.0 & 0 & 4.9 & 2.9 & 12.9 & 8.6 & 6.7 & 0 & 9.1 & 3.1 \\
\hline Staphylococcus spp. & 1.6 & 4.3 & 0 & 11.7 & 0 & 6.5 & 0 & 3.2 & 9.1 & 1.0 & 1.0 & 2.6 & 5 \\
\hline Moraxella catarrhalis & 1.1 & 12.0 & 4.4 & 3.3 & 10 & 1.0 & 2.9 & 2.7 & 5.5 & 1.0 & 12.2 & 0.8 & 0 \\
\hline Chlamydophila spp. & 1.6 & 5.3 & 20.2 & 1 & 0 & 2.4 & 26.5 & 7.2 & 3.2 & 7.6 & 0 & 5.9 & 1.3 \\
\hline Coxiella burnetii & 0 & 0 & 0 & 0.2 & 0 & 0.4 & 0 & 6.2 & 0 & 0.7 & 0 & 0.3 & 0 \\
\hline Viruses & 6.3 & 0 & 15.9 & 1.7 & 0 & 11.6 & 0 & 5.9 & 0 & 16.5 & 0 & 18.6 & 9 \\
\hline No pathogen identified & 59.8 & 52.4 & 39.8 & 35.6 & 39.4 & 67.3 & 39.8 & 56.8 & 67.1 & 35.3 & 40.6 & 38.4 & NR \\
\hline
\end{tabular}

*Data are presented as percentage means of frequency of isolation of the respective pathogens from the studies included.

NR, not reported. 
Table 2 Aetiology of community-acquired pneumonia in Europe by treatment setting ${ }^{2} 510-5355$

\begin{tabular}{llll}
\hline & \multicolumn{3}{l}{ Percentage means } \\
\cline { 2 - 4 } Pathogen & Outpatient & Hospital & Intensive care unit \\
\hline S pneumoniae & 38 & 27 & 28 \\
M pneumoniae & 8 & 5 & 2 \\
H influenzae & 13 & 6 & 7 \\
Chlamydophila pneumoniae & 21 & 11 & 4 \\
Staphylococcus aureus & 1.5 & 3 & 9 \\
Enterobacteriaceae & 0 & 4 & 9 \\
Pseudomonas aeruginosa & 1 & 3 & 4 \\
Legionella spp. & 0 & 5 & 12 \\
C burnetii & 1 & 4 & 7 \\
Respiratory viruses & 17 & 12 & 3 \\
Unclear & 50 & 41 & 45 \\
\hline
\end{tabular}

treatment of CAP. ${ }^{56}$ Several studies estimated the increase in antibiotic resistance among CAP-related pathogens in Europe (table 3). ${ }^{33} 4146$ 57-67 Although many studies found no significant correlation between antibiotic resistance and mortality, half of the studies $596062-646667$ documented appreciable increases in resistance to commonly used antibiotics. Three studies 575963 following the evolution of $S$ pneumoniae antibiotic resistance over time documented appreciable increases in resistance of $S$ pneumoniae to commonly used antibiotics.

Bruinsma and colleagues investigated penicillin and erythromycin resistance in invasive $S$ pneumoniae using data from the European Antimicrobial Resistance Surveillance System (EARSS) from 26 countries between 1999 and $2002 .{ }^{56}$ Results showed that $10 \%$ of $S$ pneumoniae isolates were penicillin non-susceptible (NS), $17 \%$ were erythromycin-NS and $6 \%$ were co-resistant. Twenty percent of penicillin-NS S pneumoniae and 33\% of erythromycinNS $S$ pneumoniae occurred in children aged $<5$ years. Of the penicillin-NS $S$ pneumoniae isolates, $78 \%$ had intermediate resistance to penicillin; $97 \%$ of isolates with reduced susceptibility to erythromycin were fully resistant. ${ }^{56}$ Penicillin and erythromycin non-susceptibility varied greatly between countries. Overall,

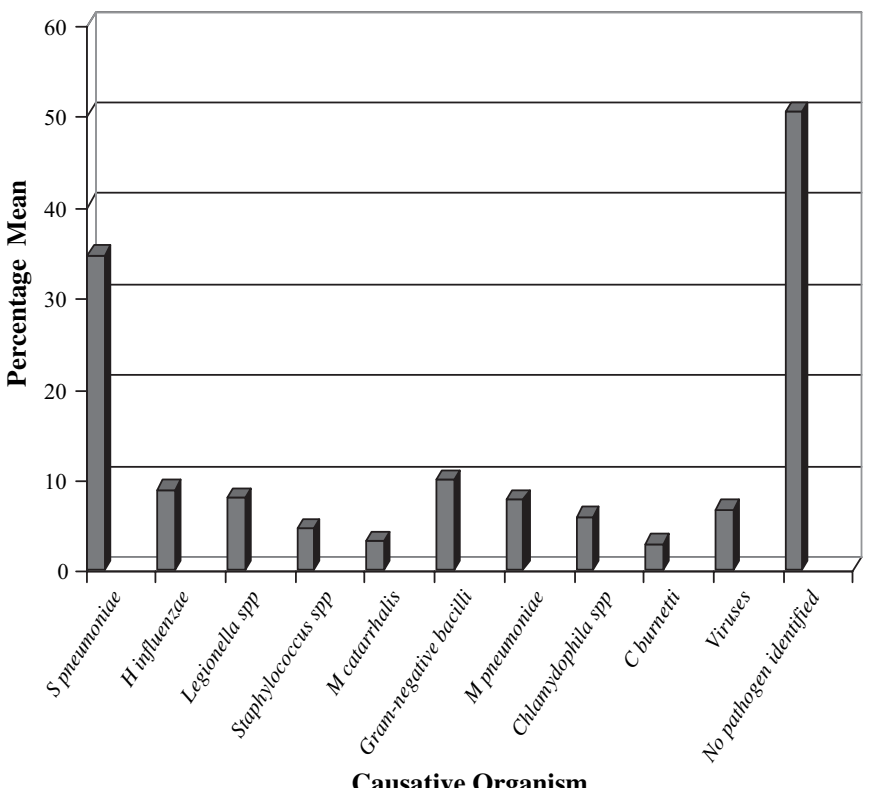

Figure 2 Frequency of causative organisms of community-acquired pneumonia (CAP) in Europe. Data are presented as percentage means of frequency of isolation of the respective pathogens from the studies included. single penicillin non-susceptibility decreased and dual nonsusceptibility increased, indicating a shift toward combined nonsusceptibility with erythromycin. The highest percentage of penicillin non-susceptibility was in southern European countries and exceeded $30 \%$ in France, Israel and Spain. For both penicillinNS and erythromycin-NS S pneumoniae, the highest percentage of resistance was in Mediterranean countries. Co-resistance was highest in Spain (18\%) and Luxembourg (12\%), followed by Belgium, Israel and Croatia with $10 \%$. The highest percentages of fully resistant strains were in Bulgaria (11\%), Spain (11\%), Israel $(6 \%)$ and Luxembourg (6\%). ${ }^{56}$

Results showed an overall $5.3 \%$ annual decrease in single penicillin non-susceptibility. Single erythromycin non-susceptibility increased for all European countries included in the study (5.9\%/year), except for the UK. Isolates with dual non-susceptibility increased by $7.6 \%$ /year. When analysed individually, no countries showed a significant increase in single penicillin nonsusceptibility. However, countries with the lowest percentage of erythromycin and dual non-susceptibility in 1999 (eg, Finland) had the highest rates of increase. When the regression model for this study was extrapolated from 1999 to 2006, single penicillin non-susceptibility decreased from $4.8 \%$ to $3.6 \%$; single erythromycin non-susceptibility increased from $14.6 \%$ to $20.4 \%$ and dual non-susceptibility increased from $5.4 \%$ to $8.9 \%$. These results are consistent with data from another antibiotic resistance surveillance project. ${ }^{68}$

\section{Clinical burden of disease: morbidity and mortality}

\section{Incidence}

Studies $^{3-5} 82428$ 69-77 show that the incidence of CAP in Europe varies by country, age and gender (table 4). In all studies, the incidence increased sharply with age and was appreciably higher in men than in women. Trotter and colleagues also observed that the incidence of hospital admission increased between 1997-1998 and 2004-2005 across all age groups. ${ }^{5}$ Although several outpatient and inpatient studies were conducted in different regions in Spain, no conclusions can be drawn about regional differences in incidence within a country because the studies were conducted during different time periods and may have had different designs.

\section{Mortality and associated risk factors}

Table 5 5-58912-14182122 243537-39 42-44464950585961-6466 67 69-71 7375 77-87 summarises mortality studies in patients with CAP. Mortality varied from $<1 \%$ to $48 \%$ and was not related to antibiotic resistance. Some variables associated with mortality were age $\geq 65$ years, female gender, use of oral corticosteroids, hospitalacquired lower respiratory tract superinfections, polymicrobial pneumonia, pleural effusion, intensive care unit (ICU) admission, atypical pneumonia, nosocomially acquired pneumonia, recent hospitalisation, serious underlying disease, acute renal failure, bacteraemic pneumonia, ineffective initial therapy, multilobar involvement, impaired alertness and septic shock. A long-term follow-up study (median=9.2 years) conducted in Finland found that elderly patients treated for CAP in both ambulatory and hospital settings had significantly higher risks of death and death related to pneumonia and cardiovascular conditions for several years following a diagnosis of pneumonia than the elderly without pneumonia. ${ }^{88}$ The risk for pneumonia-related mortality was almost threefold higher if pneumonia was pneumococcal.

\section{Effects of CAP on quality of life}

Three studies documenting the effects of CAP on HRQOL were identified. ${ }^{65} 6989$ When measuring the time it took for patients 


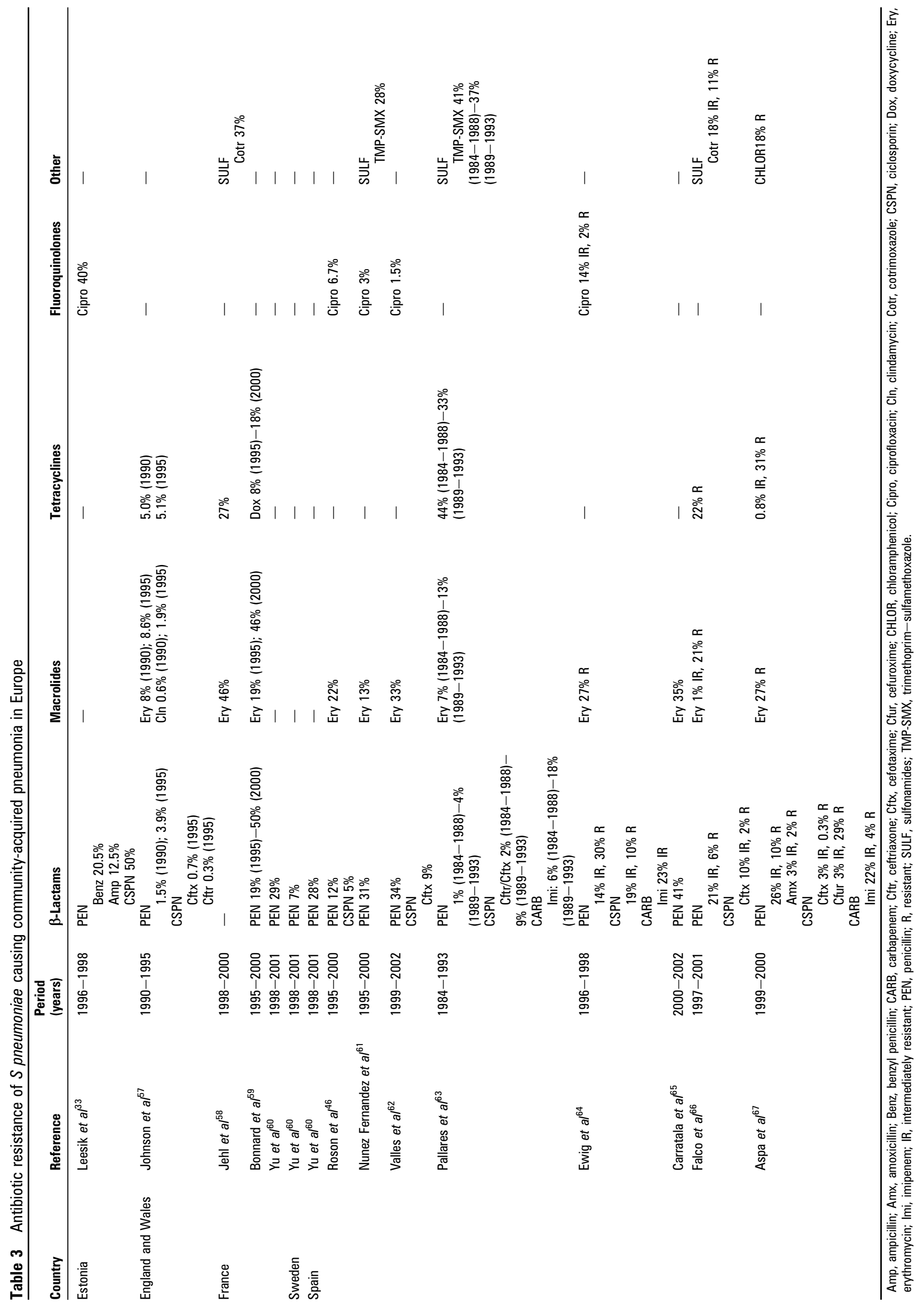


Table 4 Incidence of community-acquired pneumonia in Europe

\begin{tabular}{|c|c|c|c|}
\hline Country, investigator & $\begin{array}{l}\text { Study } \\
\text { period }\end{array}$ & Age & $\begin{array}{l}\text { Annual } \\
\text { incidence }\end{array}$ \\
\hline \multicolumn{4}{|l|}{ Outpatient treatment } \\
\hline \multirow[t]{4}{*}{ Spain, Almirall et al ${ }^{69} *$} & 1993-1995 & $15-39$ & $1.20^{\star} ; 1.09$ \\
\hline & & $40-64$ & $1.80 ; 1.49$ \\
\hline & & $>64$ & $5.20 ; 1.99$ \\
\hline & & All ages & 1.6 \\
\hline \multirow[t]{6}{*}{ Finland, Jokinen et $a l^{3} *$} & 1981-1982 & $15-29$ & $4.20 ; 4.69$ \\
\hline & & $30-44$ & $5.60^{*} ; 5.99$ \\
\hline & & $45-59$ & $9.80^{*} ; 7.09$ \\
\hline & & $60-74$ & $25.00 ; 9.09$ \\
\hline & & $\geq 75$ & $65.20 ; ; 19.6$ ㅇ \\
\hline & & $\geq 60$ & $33.00 ; 11.8$ 우 \\
\hline \multirow[t]{5}{*}{ Spain, Gutierrez et a ${ }^{28} \dagger$} & 1999-2001 & $15-44$ & $0.80^{*} ; 0.69$ \\
\hline & & $45-64$ & $1.40 ; 0.79$ \\
\hline & & $65-74$ & $3.26 ; 1.69$ \\
\hline & & $\geq 75$ & $8.7 \delta^{*} ; 3.09$ \\
\hline & & All ages & $1.60^{\star} ; 0.9$ 우 \\
\hline \multirow{4}{*}{ Spain, Ochoa-Gondar et al ${ }^{70} \neq$} & $2002-2005$ & $65-74$ & $3.00 ; 2.29$ \\
\hline & & $75-84$ & $5.30 ; 2.89$ \\
\hline & & $\geq 85$ & $10.00 ; 7.99$ \\
\hline & & All ages & $4.20 ; 2.99$ \\
\hline Spain, Vila-Corcoles et al ${ }^{8} \dagger$ & $2002-2005$ & $>65$ & 3.5 \\
\hline \multirow[t]{4}{*}{ Italy, Viegi et $a l^{71 *}$} & 1999-2000 & $15-44$ & 0.9 \\
\hline & & $45-64$ & 1.6 \\
\hline & & $>64$ & 3.3 \\
\hline & & All ages & $1.70^{\star} ; 1.79$ \\
\hline \multirow{2}{*}{\multicolumn{4}{|c|}{ Hospitalisation }} \\
\hline & & & \\
\hline \multirow{4}{*}{$\begin{array}{l}\text { England and Wales, } \\
\text { Melegaro et } \mathrm{al}^{73} *\end{array}$} & $1995-2000$ & $15-44$ & 0.2 \\
\hline & & $45-64$ & 0.5 \\
\hline & & $65-74$ & 1.5 \\
\hline & & $\geq 75$ & 4.0 \\
\hline \multirow[t]{4}{*}{ England, Trotter et $a l^{5}$ * } & 1997-2005 & $<65$ & $0.65-0.84$ \\
\hline & & $65-74$ & $2.63-3.55$ \\
\hline & & $75-84$ & $6.8-8.8$ \\
\hline & & $\geq 85$ & $16.0-22.4$ \\
\hline \multirow{3}{*}{ Italy, Rossi et al ${ }^{24} *$} & 1997-1999 & $<65$ & 0.8 \\
\hline & & $\geq 65$ & 4.8 \\
\hline & & Overall & 1.6 \\
\hline \multirow[t]{2}{*}{ Portugal, Froes ${ }^{4} *$} & $1998-2000$ & $\geq 15$ & 2.7 \\
\hline & & $\geq 65$ & 9.8 \\
\hline Spain, Carretero Gracia et $a l^{74} *$ & 1995-1996 & $\begin{array}{l}\text { Mean } 68 \\
\text { (range 42-94); } \\
43 \%>80\end{array}$ & 3.2 \\
\hline Spain, Gutierrez et al ${ }^{28 *}$ & 1999-2001 & All ages & 0.9 \\
\hline \multirow[t]{2}{*}{ Spain, Monge et al ${ }^{75} *$} & 1995-1996 & All ages & 1.6 \\
\hline & & $\geq 65$ & 5.2 \\
\hline \multirow[t]{4}{*}{ Spain, Ochoa-Gondar et al ${ }^{70} \neq$} & $2002-2005$ & $65-74$ & $11.10^{\star} ; 4.39$ \\
\hline & & $75-84$ & $19.90^{*} ; 8.71$ 우 \\
\hline & & $\geq 85$ & $29.00 ; 16.4$ 우 \\
\hline & & All ages & $15.10^{\pi} ; 7.09$ \\
\hline Spain, Vila-Corcoles et a $l^{8} \dagger$ & $2002-2005$ & $>65$ & 10.5 \\
\hline \multirow[t]{4}{*}{ Sweden, Hedlund et al ${ }^{76} \dagger$} & 1987-1988 & $18-49$ & 17 \\
\hline & & $50-64$ & 69 \\
\hline & & $65-84$ & 120 \\
\hline & & $\geq 85$ & 242 \\
\hline
\end{tabular}

*Cases per 1000 population.

†Cases per 1000 person-years.

‡Range between 1997-1998 and 2004-2005

with CAP to return to full activity, results varied with the aetiology of the infection (viral 13-33 days; bacterial 7-43 days; mixed bacterial and viral 10-50 days). ${ }^{69}$ A Spanish study measured HRQOL with the Medical Outcomes Study questionnaire (SF-36) given to ambulatory and hospitalised patients on day 7 and day 30 after they were diagnosed with pneumonia. Although the scores were not significantly different between the two groups, both groups were still subnormal compared with the general Spanish population. ${ }^{65}$ A Dutch study found a positive correlation between HRQOL and CAP scores; after 18 months, patients with CAP had significantly lower scores on physical functioning and general health components of the SF36 questionnaire than matched controls. Patients with comorbidities had significantly greater HROOL impairments in physical function, physical role function, general health and vitality than the Dutch controls. ${ }^{89}$

\section{Economic burden of disease: costs of care}

In Europe, pneumonia costs $\sim € 10.1$ billion annually, with inpatient care accounting for $€ 5.7$ billion, outpatient care $€ 0.5$ billion and drugs $€ 0.2$ billion. ${ }^{1}$ The indirect costs of lost work days amount to $€ 3.6$ billion. The high cost of care for patients with CAP has resulted in the implementation of cost-saving measures, such as reduction in hospital length of stay (LOS), the use of less expensive antibiotics and stratification of patients by severity of disease to identify those who can be cared for as ambulatory patients.

The direct and indirect costs of treating CAP were the subject of several European studies. Analysis of hospital discharge data from the Spanish national surveillance system over a 2-year period showed that the cost of hospitalisation for CAP in Spain was $€ 114.8$ million in $2001 .^{75}$ Of this amount, the care of patients aged $\geq 65$ years accounted for $€ 66.8$ million. A multicentre study in Italy estimated that the yearly costs for treating a patient with CAP, including healthcare costs during the follow-up period, were $€ 1586 .{ }^{90}$ A population-based study in Spain estimated that the mean direct costs of treatment of CAP in the ambulatory and hospital settings were $€ 196$ and $€ 1553$, respectively. ${ }^{91}$ Although costs were higher for patients aged $\geq 65$ years, the difference was statistically significant only when compared with patients aged $<65$ years who were ambulatory. ${ }^{91}$ In a prospective study in 22 hospitals in Germany, the median cost of treatment of a hospitalised patient was $€ 1201$. Costs rose as pneumonia severity index (PSI) scores increased from I to III and dropped slightly for PSI classes IV and V. This was attributed, in part, to the shorter length of treatment in non-survivors, who were only in the latter two PSI classes. ${ }^{92}$ Data from the Romanian national surveillance records show that the cost of treatment for bacteraemic and non-bacteraemic pneumococcal pneumonia in ambulatory and hospitalised patients in 2004 was $€ 8.3$ million. $^{93}$

\section{Hospital LOS}

Hospital LOS is a significant cost factor in caring for patients with CAP. When a multiple regression model was used to analyse the factors influencing LOS, interhospital variability, PSI risk class, complications during hospitalisation, ICU admission, oxygen therapy and discharge to a nursing home were associated with increased LOS. ${ }^{94}$ Another study found that low socioeconomic status independently prolonged LOS by 6 days $(95 \% \mathrm{CI}$ 2.2-9.5 days, $p \sim 0.003)$. This finding was not related to mortality, severity at presentation, number of co-morbid conditions or transfer to an ICU. Patients with low socioeconomic status were more likely to be addicted to alcohol, tobacco or drugs, and were more likely to have tuberculosis than patients with average socioeconomic status. ${ }^{95}$

A study of patients aged $\geq 65$ years with CAP found statistically significant associations between LOS and higher fever, higher number of days with fever, greater co-morbidity, urinary catheterisation and urinary infections, higher erythrocyte 
Table 5 Mortality by country and setting due to community-acquired pneumonia in Europe

\begin{tabular}{|c|c|c|}
\hline Setting & Investigator & Case-fatality rate \\
\hline \multicolumn{3}{|l|}{ Community } \\
\hline Finland & Jokinen et $a l^{3}$ & $\begin{array}{l}4 \% \text { overall; } 11 \% \geq 60 \text { years; } \\
0.6 \% 15-59 \text { years; highest } \\
\text { men } \geq 60 \text { years }\end{array}$ \\
\hline France & Fantin et $a l^{78}$ & $3.8 \%$ \\
\hline \multicolumn{3}{|l|}{$\begin{array}{l}\text { Community and } \\
\text { hospital }\end{array}$} \\
\hline Spain & Almirall et $a l^{69}$ & $5.0 \%$ \\
\hline Italy & Viegi et $a l^{71}$ & $6.0 \%$; hospitalised $>$ outpatients \\
\hline Spain & Vila-Corcoles et $a l^{8}$ & $\begin{array}{l}12.7 \% \text { overall; } 2 \% \text { outpatients, } \\
15 \% \text { hospitalised }\end{array}$ \\
\hline Spain & Ochoa-Gondar et al $^{70} *$ & $12.7 \%$; increased with age \\
\hline Germany & Kothe et $a l^{9}$ & $\begin{array}{l}6.3 \% \text { overall; } 2.2 \%<65 \text { years, } \\
10.3 \% \geq 65 \text { years }\end{array}$ \\
\hline \multicolumn{3}{|l|}{ Hospital } \\
\hline England & Venkatesan et $a l^{50}$ & $33 \%$ \\
\hline Denmark & Nielsen et $a l^{77}$ & $\begin{array}{l}17 \% \text {, all }>65 \text { years } \\
\text { (range } 21-92 \text { years) }\end{array}$ \\
\hline Spain & Rello et $a l^{44}$ & $22.4 \%$ \\
\hline Denmark & $\begin{array}{l}\text { Ostergaard and } \\
\text { Andersen }^{39}\end{array}$ & $6.3 \%$ \\
\hline The Netherlands & Bohte et $a l^{13}$ & $8 \%$ \\
\hline Spain & Pallares et $a l^{63}$ & $28 \%$ \\
\hline Switzerland & Janssens et $a l^{79}$ & $14 \%$ \\
\hline Germany & Holtermann et $a l^{80}$ & $31 \%$ \\
\hline Spain & Ewig et $a l^{64}$ & $\begin{array}{l}11 \% \text { immunocompetent; } \\
9 \% \text { immunosuppressed } \\
15 \% \text { antibiotic-resistant; } 6 \% \\
\text { antibiotic-sensitive strains }\end{array}$ \\
\hline France & Georges et $a l^{22}$ & $27.5 \%$ \\
\hline Italy & Logroscino et $a l^{81}$ & $\begin{array}{l}2.8 \% ; \text { mortality increased with } \\
\text { disease severity according to } \\
\text { Fine risk categories }\end{array}$ \\
\hline Spain & Arancibia et $a l^{82}$ & $43 \%$ \\
\hline Spain & Monge et $a l^{75}$ & $\begin{array}{l}2.7 \%<65 \text { years; } \\
11.6 \% \geq 65 \text { years }\end{array}$ \\
\hline Switzerland & Garbino et $\left.a\right|^{21}$ & $8 \%$ \\
\hline France & Jehl et $\left.a\right|^{58}$ & $16.3 \%$ \\
\hline Spain & Celis et al & $6 \%$ \\
\hline Spain & Nunez Fernandez et $a l^{61}$ & $\begin{array}{l}\text { Age }<60 \text { years: } 6.6 \% ; \\
\text { age } \geq 60 \text { years: } 15.7 \% ; \\
\text { PSI score associated }>140\end{array}$ \\
\hline Portugal & Froes $^{4}$ & $14.0 \%$; increased with age \\
\hline Spain & Aspa et $a l^{67}$ & $14.4 \%$ \\
\hline The Netherlands & Braun et $a l^{12}$ & $17.8 \%$ \\
\hline Spain & Falco et $a l^{66}$ & $\begin{array}{l}9.9-13.7 \% \text {, related to antibiotic } \\
\text { susceptibility }\end{array}$ \\
\hline Italy & Rossi et $a l^{24}$ & $\begin{array}{l}\text { Overall: } 11.2 \% \text {; } \\
\text { age } \geq 65 \text { years: } 13.8 \%\end{array}$ \\
\hline Spain & Martinez-Moragon et al ${ }^{37}$ & $\begin{array}{l}11 \% \text {; Fine severity score } \\
\text { associated }\end{array}$ \\
\hline Spain & Menendez et $a l^{83}$ & $5.6 \%$ \\
\hline France & Paganin et $a l^{42}$ & $43 \%$ \\
\hline Spain & Roson et $a l^{46}$ & $\begin{array}{l}4 \% \text { early treatment response; } \\
27 \% \text { early treatment failure }\end{array}$ \\
\hline France & Bonnard et $a l^{59}$ & $\begin{array}{l}32 \% \text {; associated with PSI } \\
\text { scores of } 90 \text { and } 130\end{array}$ \\
\hline Ireland & Foley et $a l^{84}$ & $\begin{array}{l}2 \%<65 \text { years; } \\
11.5 \%>65 \text { years }\end{array}$ \\
\hline Spain & Valles et $a l^{62}$ & $7 \%$ \\
\hline England and Wales & Melegaro et $a l^{73}$ & Range: $1-20 \%$ age related \\
\hline England & Trotter et $a l^{5}$ & $\begin{array}{l}\text { Range: } 24.8-28.2 \% \text { related } \\
\text { to year }(1997-1998 \text { to } \\
2004-2005)\end{array}$ \\
\hline
\end{tabular}

ICU

England

Alkhayer et $a l^{85}$
Table 5 Continued

\begin{tabular}{|c|c|c|}
\hline Setting & Investigator & Case-fatality rate \\
\hline Spain & Torres et $a l^{49}$ & $22 \%$ \\
\hline UK & $\begin{array}{l}\text { BTS Research } \\
\text { Committee }^{14}\end{array}$ & $48 \%$ \\
\hline $\begin{array}{l}\text { France (ICU } \\
\text { and ID unit) }\end{array}$ & Leroy et $a l^{35}$ & $28.5 \%$ \\
\hline France & Moine et $a l^{38}$ & $35 \%$ \\
\hline France & Leroy et al ${ }^{86}$ & $\begin{array}{l}19 \%<65 \text { years; } \\
30 \% \geq 65 \text { years } \\
\text { (CAP attributable) }\end{array}$ \\
\hline Spain & Rello et $a l^{87}$ & $\begin{array}{l}11.1-44.7 \% \text { related to } \\
\text { antibiotic regimen }\end{array}$ \\
\hline Spain & Rello et al ${ }^{43}$ & $23.5 \%$; age associated \\
\hline
\end{tabular}

BTS, British Thoracic Society; CAP, community-acquired pneumonia; ICU, intensive care unit; ID, infectious disease; PSI, pneumonia severity index.

*Includes ICU.

sedimentation rate, dehydration and malnutrition. ${ }^{96}$ An analysis of the influence of clinical parameters and hospital type on LOS found that hypoxaemia, low diastolic pressure, pleural effusion, multilobar pneumonia and hypoalbuminaemia were associated with increased LOS in patients in PSI risk classes III-V. ${ }^{97}$ Hypoxaemia and pleural effusion were associated with prolonged LOS in patients in the low-risk classes I and II. A study evaluating the impact of empiric antibiotic regimens on the prognosis of CAP found no associations between choice of antibiotics and hospital LOS.98

A recent study of the impact on LOS of adherence to American Thoracic Society guidelines for the treatment and management of CAP found that hospital stay was significantly longer in patients who received treatment deviating from the guidelines (10.4 days mean duration) than patients receiving treatment adhering to the guidelines (7.6 days; 2.8 days difference; $95 \%$ CI 0.93 to $4.66, p=0.004) .{ }^{99}$

Two studies conducted in Europe showed no difference in LOS whether or not patients were treated in accordance with guidelines. ${ }^{100} 101$ However, a study evaluating atypical pathogens in CAP worldwide found that antibiotic treatments that included coverage for atypical organisms led to a significantly shorter LOS; mortality rate was increased when atypicals were not covered. ${ }^{102}$

\section{Treatment and prevention}

As shown in a number of studies, the use of guidelines for treating CAP can significantly reduce morbidity and mortality. ${ }^{103-105}$ Guidelines for treatment and prevention of lower respiratory tract infections (LRTIs)-including CAP-were established by a European Respiratory Society (ERS) task force in collaboration with the European Society for Clinical Microbiology and Infectious Diseases (ESCMID). ${ }^{7}$ Recommendations for antibiotic treatment are based on illness severity, frequency of specific pathogens, local microbial resistance patterns and drug safety profiles. These guidelines also stress the possibility of a viral cause for pneumonia and offer recommendations for prevention of LRTI by vaccination and other methods. ${ }^{7}$

Empirical antibiotic coverage of atypical pathogens does not reduce mortality or improve clinical efficacy in hospitalised patients with CAP. ${ }^{106}$ There is a higher level of $S$ pneumoniae resistant to macrolides in Europe. For patients who cannot tolerate penicillins and macrolides, fluoroquinolones with Gram-positive coverage are recommended. ${ }^{107}$ Adherence to CAP guidelines also allows identification of individuals who can be managed in the outpatient setting. In addition to eliminating all hospital costs, outpatient management can decrease the risk of death, thromboembolic events and infection with resistant nosocomial bacteria. ${ }^{108}$ 


\section{DISCUSSION}

The studies reviewed here highlight the substantial clinical and economic burden of CAP in Europe. Many of these studies demonstrate appreciable increases in disease incidence and hospitalisation for CAP. They show that the elderly are disproportionately affected by CAP; moreover, death from CAP increases and $\mathrm{HROOL}$ declines with advancing age. According to the WHO, in 2002 LRTIs outranked infectious diseases such as HIV/AIDS and tuberculosis as causes of mortality among European adults. The incidence of LRTIs in Europe in 2002 (25.8 million) was second only to diarrhoeal diseases (205.5 million) and was greater than diabetes mellitus ( 2.0 million) and all malignant neoplasms combined (2.4 million). ${ }^{109}$

With the increases projected in the elderly population by 2025 , it is imperative that therapeutic interventions be developed to address the emergence of antibiotic-resistant bacterial strains causing CAP. Co-morbidities are more common among the elderly. Consequently, the clinical outcome of pneumococcal disease in elderly individuals with multiple co-morbidities can be significantly worse than in the younger population. Increases in resistance might be explained by certain patterns of antibiotic use, such as overuse for doubtful indications or low doses of oral $\beta$-lactams. ${ }^{110}$ Because resistance to erythromycin tends to be clinically relevant, ${ }^{68}$ it is more likely to lead to treatment failures and the resultant resistant strains. Although macrolides are generally a good alternative to $\beta$-lactams, treatment failures with macrolides are increasing. ${ }^{56}$ Furthermore, macrolides select for co-resistance more frequently than $\beta$-lactams, ${ }^{111}$ which would explain the increase in dual non-susceptibility to erythromycin and penicillin in countries where macrolides are preferred for children.

The ability of 23-valent pneumococcal polysaccharide vaccine (PPV) to prevent pneumonia in adults is limited. A recent meta-analysis of randomised, controlled trials pointed to the lack of evidence supporting the use of PPV to prevent allcause pneumonia or mortality. ${ }^{112}$ These observations suggested the need for improved vaccines for adults and prompted the development of new pneumococcal conjugate vaccines (PCVs). These investigational PCVs are likely to make significant contributions to reducing the burden of CAP in adults. A 13 -valent PCV is currently in late-stage clinical trials for use in adults.

This review has several limitations. Only published data were analysed. Although these data are substantial, they provide incomplete information on the burden of CAP. Data from national surveillance databases and proprietary databases, to which we did not have access, may contain information that would alter our estimates. Estimates based on data from individual countries may not be applicable to the European continent as a whole, because of country-specific differences in disease management and hospital admission criteria. Additionally, data on epidemiology and disease resistance may be skewed towards Spain, since 19 of the 46 studies identified were conducted in this country. Studies included in the analysis were all weighted equally, rather than weighted by sample size, making it difficult to compare results across studies with different sample sizes. However, we believe that by reporting the frequency of isolation of aetiological agents as percentage means from the studies included and by combining the percentage means for each country (table 1), any bias attributed to different sample sizes in individual studies is effectively addressed, and the estimates reported are an accurate representation of the situation in each country.
Because of differences in the methods used to gather and report data, studies performed in different geographic locations may not be comparable. Despite these drawbacks, this review highlights the substantial effects of CAP on adults in Europe. Improvements in the sensitivity and specificity of diagnostic assays to detect pneumococcal pneumonia, further validation and widespread use of diagnostic assays for enhanced detection of pneumococcal pneumonia and routine use of standardised definitions to report disease burden will help provide a more accurate picture of the true burden of CAP in adults.

Although the clinical and economic burden of CAP among adults in Europe is significant, data on the incidence of CAP have been wanting. A recent study analysed the inpatient records of every hospitalised patient with CAP in Germany during 2005 and 2006 (388 406 patients). ${ }^{113}$ Results showed that the incidence of hospitalised CAP in the German population was 2.75/ 1000/year in 2005 and 2.96/1000/year in 2006. The incidence was strongly age related, with an incidence of $7.65 / 1000 /$ year in patients aged $\geq 60$ years. Mortality was higher than had been reported in previous studies, with the highest risk of death occurring in the first days after hospital admission. These results confirm that CAP is a disease of the elderly. Undoubtedly, the incidence of CAP will increase in the next decade due to the ageing of the population and consequent increase of associated co-morbidities. ${ }^{113}$

For an update on the incidence, aetiology and antibiotic resistance among patients with CAP from the German Network for Community Acquired Pneumonia (CAPNETZ) registry and review data from several European countries, see the 2009 review by Welte and Kohnlein. ${ }^{114}$ For an update on the effect of hospitalised CAP on the health outcomes and resources of the elderly, see information on the currently recruiting Costs Health Status and Outcomes of CAP (CHO-CAP) study (NCT00812084) at http//www.clinicaltrials.gov. ${ }^{115}$

\section{CONCLUSIONS}

The increasing numbers of older patients hospitalised with CAP will consume a large percentage of health resources in the future. These increases in morbidity and mortality in the elderly and the considerable cost of treatment support the need to prevent CAP with an effective vaccine. PCVs based on antigens common to 7 , 10 or 13 pneumococcal serotypes are currently licenced and in late-stage clinical trials in adults. These vaccines may prevent a substantial proportion of the overall burden of CAP. Vaccination of young children may also aid in controlling antibiotic resistance in pneumococcal disease in Europe. Children are a reservoir for antibiotic-resistant pneumococci and are the most vulnerable to pneumococcal infections. ${ }^{116}$ Vaccinating this age group with PCV may be an effective tool for preventing infections caused by drug-resistant strains. In addition to preventing disease, vaccine-induced immunity reduces transmission by preventing carriage, and subsequently may contain the spread of resistant strains.

Resistance is a growing problem in Europe and the diverse nature of resistance has rendered the current European CAP treatment guidelines inadequate. In order to provide optimal treatment, national guidelines must be formulated. The possibility of an increase in erythromycin resistance, with or without reduced susceptibility to penicillin, requires intervention. The prudent use of macrolides is important in areas where resistance to penicillin and erythromycin is common. Although appropriately dosed $\beta$-lactams for empirical therapy are still the treatment of choice, macrolides should be used judiciously. ${ }^{56}$ 
Acknowledgements Assistance in manuscript preparation was provided by Excerpta Medica (Bridgewater, NJ, USA) and funded by Wyeth Pharmaceuticals, which was acquired by Pfizer Inc in October 2009.

\section{Competing interests None.}

Provenance and peer review Not commissioned; externally peer reviewed.

\section{REFERENCES}

1. Pneumonia. In: European lung white book. 2 edn. Sheffield, UK: European Respiratory Society/European Lung Foundation. 2003:55-65.

2. Jokinen C, Heiskanen L, Juvonen $\mathrm{H}$, et al. Microbial etiology of communityacquired pneumonia in the adult population of 4 municipalities in eastern Finland. Clin Infect Dis 2001;32:1141-54.

3. Jokinen C, Heiskanen $\mathrm{L}$, Juvonen $\mathrm{H}$, et al. Incidence of community-acquired pneumonia in the population of four municipalities in eastern Finland. $A m \mathrm{~J}$ Epidemiol 1993;137:977-88.

4. Froes F. Community-acquired pneumonia in adults in mainland Portugal-incidence and mortality in hospital inpatients between 1998 and 2000. Rev Port Pneumol 2003:187-94.

5. Trotter CL, Stuart JM, George R, et al. Increasing hospital admissions for pneumonia, England. Emerg Infect Dis 2008:14:727-33.

6. United Nations. United Nations, Department of Economic and Social Affairs, Population Division (2007). World Population Prospects: The Revision, Highlights, Working Paper No. ESA/PMP.202, 2006.

7. Woodhead M, Blasi F, Ewig S, et al. Guidelines for the management of adult lower respiratory tract infections. Eur Respir J 2005;26:1138-80.

8. Vila-Corcoles A, Ochoa-Gondar 0, Rodriguez-Blanco T, et al. Epidemiology of community-acquired pneumonia in older adults: a population-based study. Respir Med 2009:103:309-16.

9. Kothe H, Bauer T, Marre R, et al. Outcome of community-acquired pneumonia: influence of age, residence status and antimicrobial treatment. Eur Respir $J$ 2008;32:139-46

10. Beovic B, Bonac B, Kese D, et al. Aetiology and clinical presentation of mild communityacquired bacterial pneumonia. Eur J Clin Microbiol Infect Dis 2003;22:584-91.

11. Blanquer J, Blanquer R, Borras R, et al. Aetiology of community acquired pneumonia in Valencia, Spain: a multicentre prospective study. Thorax 1991:46:508-11

12. Braun JJ, de Graaff CS, de Goey J, et al. Community-acquired pneumonia: pathogens and course in patients admitted to a general hospital. Ned Tijdschr Geneeskd 2004:148:836-40.

13. Bohte R, van Furth R, van den Broek PJ. Aetiology of community-acquired pneumonia: a prospective study among adults requiring admission to hospital. Thorax 1995:50:543-7.

14. The British Thoracic Society Research Committee and The Public Health Laboratory Service. The aetiology, management and outcome of severe community-acquired pneumonia on the intensive care unit. Respir Med 1992;86:7-13.

15. Carrillo de Albornoz MM, Perez de Heredia JH, Sanchez Alvarez J, et al. Epidemiology of the pneumonias in health area 1 of Navarra community. Med Clin (Barc) 1991;97:50-2.

16. Carr B, Walsh JB, Coakley D, et al. Prospective hospital study of community acquired lower respiratory tract infection in the elderly. Respir Med 1991:85:185-7.

17. Castro-Guardiola A, Armengou A, Garcia D, et al. Prospective study of 198 cases of community-acquired pneumonia treated in a general hospital. Enferm Infecc Microbiol Clin 1999:17:213-18.

18. Celis MR, Torres A, Zalacain R, et al. Methods for diagnosing and treating community-acquired pneumonia in Spain: NACE study. Med Clin (Barc) 2002;119:321-6.

19. Erard V, Lamy 0, Bochud P-Y, et al. Full-course oral levofloxacin for treatment of hospitalized patients with community-acquired pneumonia. Eur J Clin Microbiol Infect Dis 2004;23:82-8.

20. Fernandez Alvarez R, Suarez Toste I, Rubinos Cuadrado G, et al. Communityacquired pneumonia: aetiologic changes in a limited geographic area. An 11-year prospective study. Eur J Clin Microbiol Infect Dis 2007:26:495-9.

21. Garbino J, Sommer R, Gerber A, et al. Prospective epidemiologic survey of patients with community-acquired pneumonia requiring hospitalization in Switzerland. Int $J$ Infect Dis 2002;6:288-93.

22. Georges $\mathbf{H}$, Leroy 0 , Vandenbussche $\mathrm{C}$, et al. Epidemiological features and prognosis of severe community-acquired pneumococcal pneumonia. Intensive Care Med 1999;25:198-206

23. Garcia Vazquez E, Mensa J, Martinez JA, et al. Lower mortality among patients with community-acquired pneumonia treated with a macrolide plus a beta-lactam agent versus a beta-lactam agent alone. Eur J Clin Microbiol Infect Dis 2005;24:190-5.

24. Rossi PG, Agabiti N, Faustini A, et al. The burden of hospitalised pneumonia in Lazio, Italy, 1997-1999. Int J Tuberc Lung Dis 2004;8:528-36.

25. Gomez J, Banos V, Ruiz Gomez J, et al. Prospective study of epidemiology and prognostic factors in community-acquired pneumonia. Eur J Clin Microbiol Infect Dis 1996;15:556-60.
26. Guglielmo L, Leone R, Veneto Pneumonia Research Group. Aetiology and therapy of community-acquired pneumonia: a hospital study in northern Italy. Eur J Clin Pharmacol 1997;51:437-43.

27. Javier Alvarez GF, del Castillo OD, Garcia FA, et al. [Prospective study of 221 community-acquired pneumonia cases followed up in an outpatient clinic. Etiology and clinical-radiological progression]. Med Clin (Barc) 2001;116:161-6.

28. Gutierrez F, Masia M, Mirete $C$, et al. The influence of age and gender on the population-based incidence of community-acquired pneumonia caused by different microbial pathogens. J Infect 2006:53:166-74.

29. Holm A, Nexoe J, Bistrup LA, et al. Aetiology and prediction of pneumonia in lower respiratory tract infection in primary care. Br J Gen Pract 2007;57:547-54.

30. Hoogewerf $\mathbf{M}$, Oosterheert JJ, Hak $E$, et al. Prognostic factors for early clinical failure in patients with severe community-acquired pneumonia. Clin Microbiol Infect 2006;12:1097-104.

31. Juega J, Montero Martinez C, Pedreira JD, et al. Community-acquired pneumonia requiring hospitalization. Etiological aspects and follow up among 366 cases An Med Interna 1998;15:421-6.

32. Laurichesse H, Sotto A, Bonnet E, et al, Infectio-Sud Study Group. Pre- and in-hospital management of community-acquired pneumonia in southern France, 1998-99. Eur J Clin Microbiol Infect Dis 2001:20:770-8.

33. Leesik H, Ani U, Juhani A, et al. Microbial pathogens of adult community-acquired pneumonia in Southern Estonia. Medicina (Kaunas) 2006;42:384-94.

34. Leroy 0, Georges $\mathrm{H}$, Beuscart $\mathrm{C}$, et al. Severe community-acquired pneumonia in ICUs: prospective validation of a prognostic score. Intensive Care Med 1996;22:1307-14.

35. Leroy 0, Santre C, Beuscart C, et al. A five-year study of severe communityacquired pneumonia with emphasis on prognosis in patients admitted to an intensive care unit. Intensive Care Med 1995:21:24-31.

36. Lim WS, Macfarlane JT, Boswell TCJ, et al. Study of community acquired pneumonia aetiology (SCAPA) in adults admitted to hospital: implications for management guidelines. Thorax 2001:56:296-301.

37. Martinez-Moragon E, Garcia Ferrer L, Serra Sanchos B, et al. Community-acquired pneumonia among the elderly: differences between patients living at home and in nursing homes. Arch Bronconeumol 2004:40:547-52.

38. Moine P, Vercken JB, Chevret S, et al; The French Study Group of CommunityAcquired Pneumonia in ICU. Severe community-acquired pneumococcal pneumonia. Scand J Infect Dis 1995;27:201-6.

39. Ostergaard L, Andersen PL. Etiology of community-acquired pneumonia: evaluation by transtracheal aspiration, blood culture, or serology. Chest 1993:104:1400-7.

40. Ozyilmaz E, Akan OA, Gulhan $\mathrm{M}$, et al. Major bacteria of community-acquired respiratory tract infections in Turkey. Jpn J Infect Dis 2005;58:50-2.

41. Paganin F, Chanez $\mathrm{P}$, Brousse $\mathrm{C}$, et al. Community-acquired pneumonia in the Montpellier region: rise in frequency of reduced penicillin-sensitive pneumococci. Presse Med 1995;24:1341-4.

42. Paganin F, Lilienthal F, Bourdin A, et al. Severe community-acquired pneumonia: assessment of microbial aetiology as mortality factor. Eur Respir J 2004;24:779-85.

43. Rello J, Bodi M, Mariscal D, et al. Microbiological testing and outcome of patients with severe community-acquired pneumonia. Chest 2003;123:174-80.

44. Rello J, Quintana E, Ausina V, et al. A three-year study of severe communityacquired pneumonia with emphasis on outcome. Chest 1993:103:232-5.

45. Riquelme R, Torres A, El-Ebiary $M$, et al. Community-acquired pneumonia in the elderly: a multivariate analysis of risk and prognostic factors. Am J Respir Crit Care Med 1996;154:1450-5.

46. Roson B, Carratala J, Fernandez-Sabe N, et al. Causes and factors associated with early failure in hospitalized patients with community-acquired pneumonia. Arch Intern Med 2004:164:502-8.

47. Sanguinetti CM, De Benedetto F, Miragliotta G; DEDALO Study Group. Bacterial agents of lower respiratory tract infections (LRTIs), $\beta$-lactamase production, and resistance to antibiotics in elderly people. Int $J$ Antimicrob Agents 2000;16:467-71

48. Sopena N, Sabria M, Pedro-Botet ML, et al. Prospective study of communityacquired pneumonia of bacterial etiology in adults. Eur J Clin Microbiol Infect Dis 1999; 18:852-8

49. Torres A, Serra-Batlles J, Ferrer A, et al. Severe community-acquired pneumonia: epidemiology and prognostic factors. Am Rev Respir Dis 1991;144:312-18.

50. Venkatesan P, Gladman J, Macfarlane JT, et al. A hospital study of community acquired pneumonia in the elderly. Thorax 1990:45:254-8

51. Zalacain R, Torres A, Celis $R$, et al. Community-acquired pneumonia in the elderly: Spanish multicentre study. Eur Respir J 2003;21:294-302.

52. Welte T, Marre R, Suttorp N. What is new in the treatment of community-acquired pneumonia? Med Klin (Munich) 2006;101:313-20.

53. Welte T. Reply to Solnick and to Leenders letter. Clin Infect Dis 2006:43:110-11.

54. Woodhead M. Community-acquired pneumonia in Europe: causative pathogens and resistance patterns. Eur Respir J 2002;20(Suppl 36):20s-7s.

55. Hoffken G, Lorenz J, Kern W, et al. S3-guideline on ambulant acquired pneumonia and deep airway infections. Pneumologie 2005;59:612-64.

56. Bruinsma N, Kristinsson KG, Bronzwaer $\mathrm{S}$, et al. Trends of penicillin and erythromycin resistance among invasive Streptococcus pneumoniae in Europe. J Antimicrob Chemother 2004;54:1045-50.

57. Johnson AP, Speller DCE, George RC, et al. Prevalence of antibiotic resistance and serotypes in pneumococci in England and Wales: results of observational surveys in 1990 and 1995. BMJ 1996;312:1454-6. 
58. Jehl F, Bedos J-P, Poirier R, et al. Nationwide survey on community-acquired pneumococcal pneumonia necessitating hospitalization. Med Mal Infect 2002; 32:267-83.

59. Bonnard P, Lescure FX, Douadi $Y$, et al. Community-acquired bacteraemic pneumococcal pneumonia in adults: effect of diminished penicillin susceptibility on clinical outcome. J Infect 2005:51:69-76.

60. Yu VL, Chiou CC, Feldman C, et al. An international prospective study of pneumococcal bacteremia: correlation with in vitro resistance, antibiotics administered, and clinical outcome. Clin Infect Dis 2003:37:230-7.

61. Nunez Fernandez MJ, De Castro R0, Lueiro Lores F, et al. Pneumococcal pneumonia with bacteremia in adults: a descriptive study from northwestern Spain. An Med Interna 2002;19:612-20.

62. Valles X, Marcos A, Pinart $M$, et al. Hospitalized community-acquired pneumonia due to Streptococcus pneumoniae: has resistance to antibiotics decreased? Chest 2006;130:800-6.

63. Pallares R, Linares J, Vadillo $\mathrm{M}$, et al. Resistance to penicillin and cephalosporin and mortality from severe pneumococcal pneumonia in Barcelona, Spain. $N$ Engl J Med 1995;333:474-80

64. Ewig S, Ruiz M, Torres A, et al. Pneumonia acquired in the community through drug-resistant Streptococcus pneumoniae. Am J Respir Crit Care Med 1999; 159:1835-42

65. Carratala J, Fernandez-Sabe N, Ortega L, et al. Outpatient care compared with hospitalization for community-acquired pneumonia: a randomized trial in low-risk patients. Ann Intern Med 2005;142:165-72.

66. Falco V, Almirante B, Jordano 0 , et al. Influence of penicillin resistance on outcome in adult patients with invasive pneumococcal pneumonia: is penicillin useful against intermediately resistant strains? J Antimicrob Chemother 2004:54:481-8.

67. Aspa J, Rajas 0, Rodriguez de Castro F, et al. Drug-resistant pneumococcal pneumonia: clinical relevance and related factors. Clin Infect Dis 2004;38:787-98.

68. Jacobs MR, Felmingham D, Appelbaum PC, et al. The Alexander Project 1998-2000: susceptibility of pathogens isolated from community-acquired respiratory tract infection to commonly used antimicrobial agents. J Antimicrob Chemother 2003;52:229-46.

69. Almirall J, Bolibar I, Vidal J, et al. Epidemiology of community-acquired pneumonia in adults: a population-based study. Eur Respir J 2000;15:757-63.

70. Ochoa-Gondar 0, Vila-Corcoles A, de Diego C, et al. The burden of communityacquired pneumonia in the elderly: the Spanish EVAN-65 study. BMC Public Health 2008;8:222.

71. Viegi G, Pistelli $R$, Cazzola $M$, et al. Epidemiological survey on incidence and treatment of community acquired pneumonia in Italy. Respir Med 2006;100:46-55.

72. Schnoor M, Hedicke J, Dalhoff K, et al. Approaches to estimate the populationbased incidence of community acquired pneumonia. J Infect 2007;55:233-9.

73. Melegaro A, Edmunds WJ, Pebody R, et al. The current burden of pneumococcal disease in England and Wales. J Infect 2006:52:37-48.

74. Carretero Gracia JA, Nebreda Mayoral T, Acereda Ridruejo Al, et al. Communityacquired pneumonia referred for hospital management. Epidemiology and diagnostic and therapeutic approach. Arch Bronconeumol 1999;35:27-32.

75. Monge V, San-Martin M, Gonzalez A. The burden of community-acquired pneumonia in Spain. Eur J Public Health 2001:11:362-4.

76. Hedlund JU, Ortqvist $A B$, Kalin $M$, et al. Risk of pneumonia in patients previously treated in hospital for pneumonia. Lancet 1992;340:396-7.

77. Nielsen SV, Poullsen K, Jorgensen LM, et al. Incidence and diagnosis of cases of pneumonia caused by pneumococci that require hospitalisation. Ugeskr Laeger 1992:154:412-15.

78. Fantin B, Aubert JP, Unger $\mathrm{P}$, et al. Clinical evaluation of the management of community-acquired pneumonia by general practitioners in France. Chest 2001;120:185-92.

79. Janssens J-P, Gauthey L, Herrmann F, et al. Community-acquired pneumonia in older patients. J Am Geriatr Soc 1996;44:539-44.

80. Holtermann W, Kramer M, Geppert $\mathrm{P}$, et al. Epidemiology, clinical course and prognosis of severe progressive forms of community-acquired pneumonias. Pneumologie 1998;52:263-70.

81. Logroscino CD, Penza 0, Locicero $S$, et al. Community-acquired pneumonia in adults: a multicentric observational AIPO study. Monaldi Arch Chest Dis 1999:54:11-17.

82. Arancibia F, Ewig S, Martinez JA, et al. Antimicrobial treatment failures in patients with community-acquired pneumonia: causes and prognostic implications. Am J Respir Crit Care Med 2000;162:154-60

83. Menendez R, Torres A, Zalacain R, et al. Risk factors of treatment failure in community acquired pneumonia: implications for disease outcome. Thorax 2004:59:960-5.

84. Foley SC, Kelly EM, O'Neill SJ. Audit of the management of patients admitted with community acquired pneumonia. Ir Med J 2006:99:138-40.

85. Alkhayer M, Jenkins PF, Harrison BDW. The outcome of community acquired pneumonia treated on the intensive care unit. Respir Med 1990;84:13-16.

86. Leroy $\mathbf{0}$, Bosquet $\mathrm{C}$, Vandenbussche $\mathrm{C}$, et al. Community-acquired pneumonia in the intensive care unit: epidemiological and prognosis data in older people. J Am Geriatr Soc 1999;47:539-46.

87. Rello J, Catalan M, Diaz E, et al. Associations between empirical antimicrobial therapy at the hospital and mortality in patients with severe community-acquired pneumonia. Intensive Care Med 2002;28:1030-5.
88. Koivula I, Sten M, Makela PH. Prognosis after community-acquired pneumonia in the elderly: a population-based 12-year follow-up study. Arch Intern Med 1999;159:1550-5

89. El Moussaoui R, Opmeer BC, de Borgie CAJM, et al. Long-term symptom recovery and health-related quality of life in patients with mild-to-moderate-severe community-acquired pneumonia. Chest 2006;130:1165-72.

90. Dal Negro R, Berto P, Tognella $S$, et al. Cost-of-illness of lung disease in the TriVeneto Region, Italy: the GOLD Study. Monaldi Arch Chest Dis 2002:57:3-9.

91. Bartolome M, Almirall J, Morera J, et al. A population-based study of the costs of care for community-acquired pneumonia. Eur Respir J 2004;23:610-16.

92. Bauer TT, Welte T, Ernen C, et al. Cost analyses of community-acquired pneumonia from the hospital perspective. Chest 2005;128:2238-46.

93. Stoicescu IP, Mihaescu T, Azoicai D, et al. [Preliminary assessment of Streptococcus pneumoniae pneumonia, economical and clinical burden in Romania] Pneumologia 2007;56:118-23.

94. Cabre M, Bolivar I, Pera G, et al. Factors influencing length of hospital stay in community-acquired pneumonia: a study in 27 community hospitals. Epidemiol Infect 2004;132:821-9.

95. Stelianides S, Golmard JL, Carbon C, et al. Influence of socioeconomic status on features and outcome of community-acquired pneumonia. Eur J Clin Microbiol Infect Dis 1999; 18:704-8

96. Masotti L, Ceccarelli E, Cappelli R, et al. Length of hospitalization in elderly patients with community-acquired pneumonia. Aging Clin Exp Res 2000;12:35-41.

97. Menendez R, Cremades MJ, Martinez-Moragon E, et al. Duration of length of stay in pneumonia: influence of clinical factors and hospital type. Eur Respir $J$ 2003;22:643-8

98. Reyes Calzada S, Martinez Tomas R, Cremades Romero MJ, et al. Empiric treatment in hospitalized community-acquired pneumonia. Impact on mortality, length of stay and re-admission. Respir Med 2007;101:1909-15.

99. Dambrava PG, Torres A, Valles $X$, et al. Adherence to guidelines' empirical antibiotic recommendations and community-acquired pneumonia outcome. Eur Respir J 2008;32:892-901

100. Garau J, Baquero F, Pérez-Trallero E, et al. Factors impacting on length of stay and mortality of community-acquired pneumonia. Clin Microbiol Infect 2008; 14:322-9

101. Menéndez R, Ferrando D, Vallés JM, et al. Influence of deviation from guidelines on the outcome of community-acquired pneumonia. Chest 2002;122:612-17.

102. Arnold FW, Summersgill JT, Lajoie AS, et al. A worldwide perspective of atypical pathogens in community-acquired pneumonia. Am J Respir Crit Care Med 2007; 175:1086-93.

103. Dean NC, Silver MP, Bateman KA, et al. Decreased mortality after implementation of a treatment guideline for community-acquired pneumonia. Am J Med 2001;110:451-7.

104. Capelastegui A, Espana PP, Quintana JM, et al. Improvement of process-of-care and outcomes after implementing a guideline for the management of communityacquired pneumonia: a controlled before-and-after design study. Clin Infect Dis 2004:39:955-63.

105. Mortensen EM, Restrepo M, Anzueto A, et al. Effects of guideline-concordant antimicrobial therapy on mortality among patients with community-acquired pneumonia. Am J Med 2004:117:726-31.

106. Mandell LA, Bartlett JG, Dowell SF, et al. Update of practice guidelines for the management of community-acquired pneumonia in immunocompetent adults. Clin Infect Dis 2003;37:1405-33.

107. Lode HM. Managing community-acquired pneumonia: a European perspective. Respir Med 2007;101:1864-73.

108. Marrie TJ, Lau CY, Wheeler SL, et al, CAPITAL Study Investigators. CommunityAcquired Pneumonia Trial Assessing Levofloxacin. A controlled trial of a critical pathway for treatment of community-acquired pneumonia. CAPITAL Study Investigators Community-Acquired Pneumonia Trial Assessing Levofloxacin. JAMA 2000;283:749-55.

109. World Health Organization. Revised Global Burden of Disease (GBD) 2002 Estimates: Incidence, Prevalence, Mortality, YLL, YLD and DALYS by Sex, Cause and Region, Estimates for 2004. Washington, DC: World Health Organization, 2004. http://www.who.int/healthinfo/global burden disease/estimates regional 2002 revised/en/index.html (accessed 18 Mar 2010).

110. Harbarth S, Albrich W, Goldmann DA, et al. Control of multiply resistant cocci: do international comparisons help? Lancet Infect Dis 2001:1:251-61.

111. Baquero F. Evolving resistance patterns of Streptococcus pneumoniae: a link with long-acting macrolide consumption? J Chemother 1999:11:35-43.

112. Moberley SA, Holden J, Tatham DP, et al. Vaccines for preventing pneumococcal infection in adults. Cochrane Database Syst Rev 2008;(1):CD000422.

113. Ewig S, Birkner N, Strauss R, et al. New perspectives on community-acquired pneumonia in 388,406 patients. Thorax 2009;64:1062-9.

114. Welte T, Kohnlein T. Global and local epidemiology of community-acquired pneumonia: the experience of the CAPNETZ Network. Semin Respir Crit Care Med 2009;30:127-35.

115. ClinicalTrials.gov. Costs, health status and outcomes of CAP (communityacquired pneumonia) (CHO-CAP). http://www.clinicaltrials.gov/ct2/show/ NCT00812084?term=CHO-CAPgrank=1 (accessed 23 Jun 2009).

116. Whitney CG, Farley MM, Hadler J, et al. Decline in invasive pneumococcal disease after the introduction of protein-polysaccharide conjugate vaccine. N Engl J Med 2003;348:1737-46. 